\section{Two Novel Guaiane Sesquiterpenes from the Whole Plant of Youngia japonica}

\author{
ji Young Lee ${ }^{1,2}$, Mi-Ran Cha ${ }^{1}$, Mi Ri Kim ${ }^{1}$, Kwangho Lee ${ }^{1}$, \\ Sang-Un Choi ${ }^{1}$, Shi Yong Ryu ${ }^{1,2}$ \\ ${ }^{1}$ Research Center for Medicinal Chemistry, Korea Research \\ Institute of Chemical Technology, Daejeon, Korea \\ ${ }^{2}$ Graduate School of New Drug Discovery and Development, \\ Chungnam National University, Daejeon, Korea
}

\section{Abstract \\ $\nabla$}

Two new guaiane-type sesquiterpenes (1 and 2) together with eight related sesquiterpenoidal constituents (3-10) were isolated from the whole extract of Youngia japonica. The chemical structures of 1-10 were established by spectroscopic analyses as 4epi-isolipidiol (1), 4'-p-hydroxyphenylacetyl crepiside E (2), isolipidiol (3), isoambeboin (4), grosheimin (5), annuionone D (6), loliolide (7), youngiajaponicoside A (8), crepiside H (9), and crepiside E (10), respectively. Among the isolated components, 5 exhibited a significant inhibitory effect on the proliferation of cultured human tumor cell lines (A549, SK-OV-3, SK-MEL-2, and HCT15).

\section{Key words}

Youngia japonica - Asteraceae - guaiane sesquiterpene - cytotoxicity

Supporting information available online at http://www.thieme-connect.de/products

Youngia japonica (L.) DC. (Asteraceae) is a biannual herbaceous plant, native to Korea, China, and Japan that is widely spread on roadsides, gardens, and waste areas [1]. The young leaves and stalks are employed as a wild vegetable and are also used as wild health food for salads in North America. It is frequently used in traditional Chinese medicine for the treatment of inflammatory diseases, such as angina, leucorrhea, and rheumatoid arthritis. Moreover, it is utilized as an internal remedy for colds and sore throats, and the paste is used for external application to relieve the symptoms of boils, mastitis, and bruises due to sprain $[2,3]$. Several sesquiterpenoidal constituents [4-6] were reported to be purified from $Y$. japonica, which were considered of great interest to show an effect on the regulation and prevention of diverse biological damage [7-9]. In the course of a phytochemical investigation of $Y$. japonica, two new guaiane-type sesquiterpenes (1 and 2) together with eight related known sesquiterpenes (3-10) were isolated ( 0 Fig. 1). In the present paper, we describe briefly the identification of two new compounds, 1 and $\mathbf{2}$, as well as the inhibitory effect of isolated sesquiterpenes on the proliferation of four cultured human tumor cell lines, in vitro.

Compound 1 was obtained as a white amorphous powder, $[\alpha]_{D}^{20}$ +11.7 (c $0.20, \mathrm{CH}_{3} \mathrm{OH}$ ). The molecular formula of 1 was established as $\mathrm{C}_{15} \mathrm{H}_{22} \mathrm{O}_{4}$ at $\mathrm{m} / z 289.1426$ (calcd. 289.1410) $[\mathrm{M}+\mathrm{Na}]^{+}$ by HR-ESI-MS, identical with that of isolipidiol (3). The chemical shifts and coupling constants of all of the proton signals of 1 were highly similar to those of $\mathbf{3}$, which implied that $\mathbf{1}$ might be an isomer of 3. Thus, all proton signals and carbon signals of 1 were completely identified by the aid of two-dimensional NMR experiments such as COSY, DEPT, HMQC, HMBC, and ROESY ( Table 1), which concluded that the planar structure of 1 was identical with that of $\mathbf{3}$, i.e., $\mathbf{1}$ was a stereoisomer of $\mathbf{3}$. Compound $\mathbf{3}$ is a representative sesquiterpene found in the species and the absolute configuration of $\mathbf{3}$ was completely established by 2-D NMR experiment and by X-ray diffraction analysis as depicted in - Figs. 2 and 3. Actually, three stereoisomers of isolipidiol (3), i. e., lipidiol (11-epi-isolipidiol) [10], 8-epi-isolipidiol [11], and 4,8epi-isolipidiol [11], have been reported so far. However, the proton signals of $\mathbf{1}$ were not matched with those of $\mathbf{3}$ or with those of the other three reported stereoisomers either. When the proton NMR spectrum of $\mathbf{1}$ was compared with that of $\mathbf{3}$, the signals of $\mathrm{H}$ -

$$
\text { (n) }
$$

Fig. 1 Structures of isolated compounds (1-10) from $Y$. japonica. 


\begin{tabular}{|c|c|c|c|c|c|}
\hline Pos. & $1\left(\delta_{\mathrm{H}}\right)$ & $3\left(\delta_{\mathrm{H}}\right)$ & $1\left(\delta_{C}\right)$ & $3\left(\delta_{C}\right)$ & \multirow{19}{*}{$\begin{array}{l}\text { Table } 1{ }^{1} \mathrm{H} \text { - and }{ }^{13} \mathrm{C}-\mathrm{NMR} \text { spec- } \\
\text { troscopic data of } \mathbf{1} \text { and } 3 \text {. Assign- } \\
\text { ments are based on } \mathrm{HMQC} \text { and } \\
\mathrm{HMBC} \text { experiments, and chemical } \\
\text { shifts are given in ppm. }\end{array}$} \\
\hline 1 & $2.75(1 \mathrm{H}, \mathrm{m})$ & $2.79(1 \mathrm{H}, \mathrm{m})$ & 41.9 & 43.0 & \\
\hline \multirow[t]{2}{*}{2} & $2.13(1 \mathrm{H}, \mathrm{m})$ & $2.02(1 \mathrm{H}, \mathrm{m})$ & \multirow[t]{2}{*}{35.8} & \multirow[t]{2}{*}{39.6} & \\
\hline & $2.27(1 \mathrm{H}, \mathrm{m})$ & $2.24(1 \mathrm{H}, \mathrm{m})$ & & & \\
\hline 3 & $4.46(1 \mathrm{H}, \mathrm{m})$ & $3.91(1 \mathrm{H}, \mathrm{m})$ & 73.6 & 78.1 & \\
\hline 4 & $2.50(1 \mathrm{H}, \mathrm{m})$ & $2.14(1 \mathrm{H}, \mathrm{m})$ & 42.0 & 47.9 & \\
\hline 5 & $2.29(1 \mathrm{H}, \mathrm{dd}, J=6.4,11.2 \mathrm{~Hz})$ & $1.98(1 \mathrm{H}, \mathrm{m})$ & 48.5 & 51.5 & \\
\hline 6 & $4.24(1 \mathrm{H}, \mathrm{dd}, J=11.0,11.2 \mathrm{~Hz})$ & $3.93(1 \mathrm{H}, \mathrm{m})$ & 79.1 & 82.5 & \\
\hline 7 & $2.20(1 \mathrm{H}, \mathrm{ddd}, J=9.6,10.0,10.4 \mathrm{~Hz})$ & $2.18(1 \mathrm{H}, \mathrm{ddd}, J=9.6,10.0,10.4 \mathrm{~Hz})$ & 57.9 & 59.2 & \\
\hline 8 & $3.89(1 \mathrm{H}, \mathrm{m})$ & $3.83(1 \mathrm{H}, \mathrm{m})$ & 75.9 & 76.3 & \\
\hline \multirow[t]{2}{*}{9} & $2.27(1 \mathrm{H}, \mathrm{dd}, J=11.8,12.0 \mathrm{~Hz})$ & $2.35(1 \mathrm{H}, \mathrm{dd}, J=11.8,12.8 \mathrm{~Hz})$ & \multirow[t]{2}{*}{51.1} & \multirow[t]{2}{*}{48.9} & \\
\hline & $3.08(1 \mathrm{H}, \mathrm{dd}, J=4.0,12.0 \mathrm{~Hz})$ & $3.00(1 \mathrm{H}, \mathrm{dd}, J=4.8,12.8 \mathrm{~Hz})$ & & & \\
\hline 10 & & & 145.5 & 146.1 & \\
\hline 11 & $2.90(1 \mathrm{H}, \mathrm{m})$ & $2.77(1 \mathrm{H}, \mathrm{m})$ & 42.6 & 42.9 & \\
\hline 12 & & & 179.7 & 179.5 & \\
\hline 13 & $1.71(3 \mathrm{H}, \mathrm{d}, J=7.2 \mathrm{~Hz})$ & $1.68(3 \mathrm{H}, \mathrm{d}, J=7.2 \mathrm{~Hz})$ & 17.4 & 19.0 & \\
\hline \multirow[t]{2}{*}{14} & $5.05(1 \mathrm{H}, \mathrm{brs})$ & $4.99(1 \mathrm{H}, \mathrm{brs})$ & \multirow[t]{2}{*}{113.5} & \multirow[t]{2}{*}{114.2} & \\
\hline & $5.16(1 \mathrm{H}, \mathrm{brs})$ & $5.09(1 \mathrm{H}, \mathrm{brs})$ & & & \\
\hline 15 & $1.25(3 \mathrm{H}, \mathrm{d}, J=7.2 \mathrm{~Hz})$ & $1.44(3 \mathrm{H}, \mathrm{d}, J=6.4 \mathrm{~Hz})$ & 9.2 & 17.0 & \\
\hline
\end{tabular}

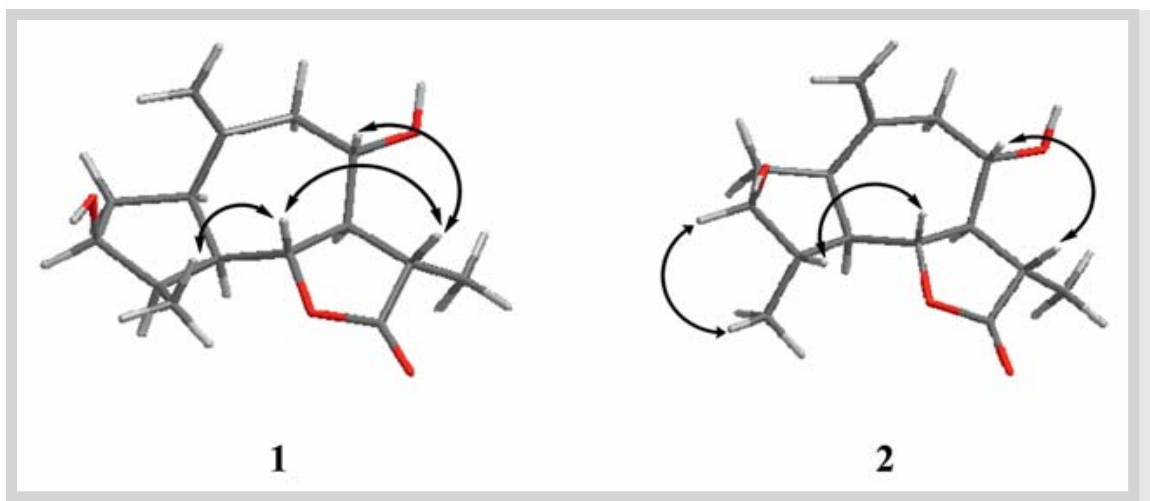

Fig. 2 Correlations observed in selected ROESY spectra of $\mathbf{1}$ and $\mathbf{2}$.

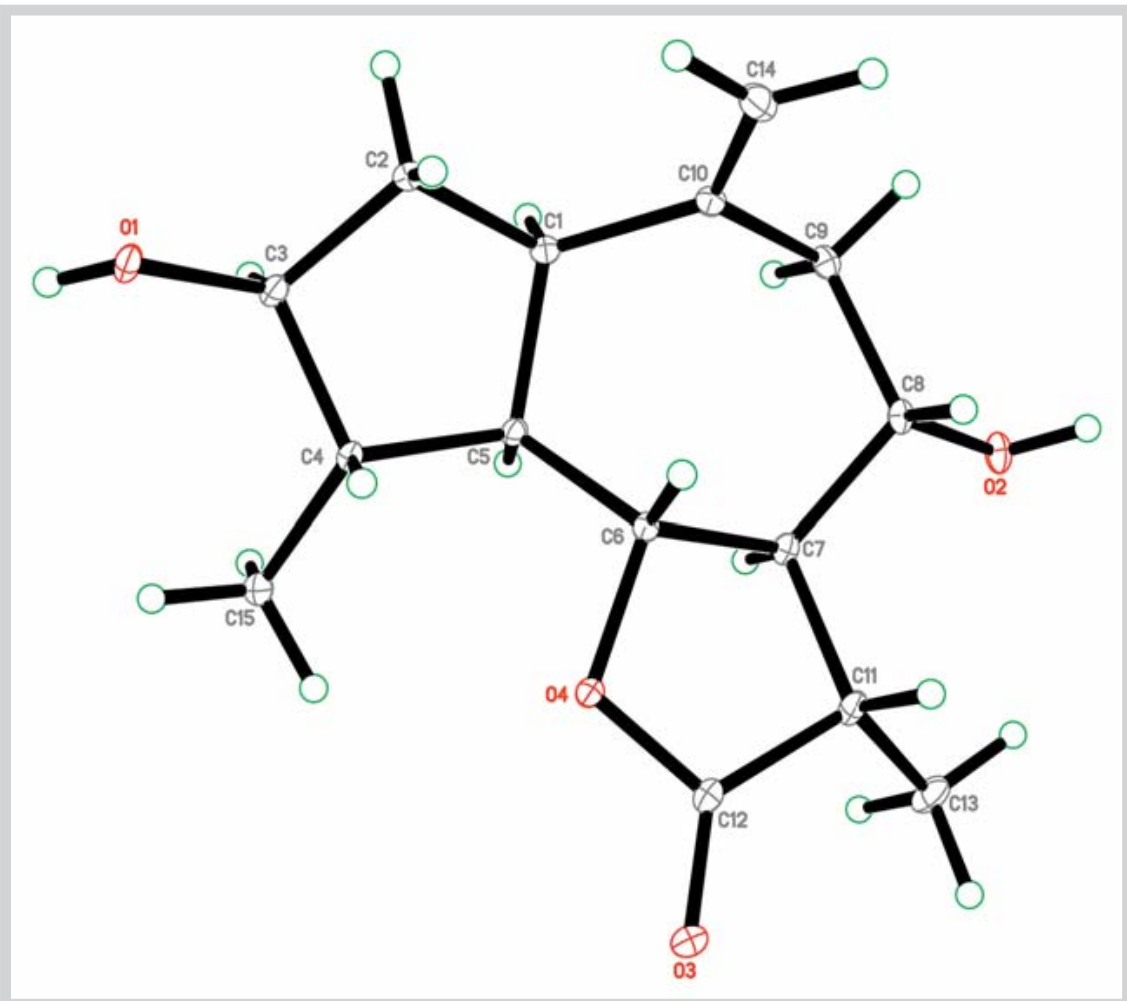

Fig. 3 X-ray crystallographic analysis of $\mathbf{2}$. 
$3, \mathrm{H}-4$, and $\mathrm{H}-5$ of 1 were shifted downfield $(\Delta \delta+0.6,+0.4,+0.3)$, whereas that of $\mathrm{H}-15$ was shifted to upfield $(\Delta \delta-0.2)$ ( $\bullet$ Table 1 ). Moreover, the ROESY spectra of $\mathbf{1}$ and $\mathbf{3}$ displayed different correlations. Particularly, H-6 of 1 was correlated with methyl protons (H-15) attached at C-4, whereas $\mathrm{H}-6$ of 3 was correlated with $\mathrm{H}-4$ (๑ Fig. 2). These spectroscopic evidences suggested that methyl group attached at C-4 of $\mathbf{1}$ had the opposite orientation compared with 3 and concluded that 1 was a 4 -epimer of $\mathbf{3}$. Thus, the chemical structure of $\mathbf{1}$ was established as 4-epi-isolipidiol as depicted in $\bullet$ Figs. 1 and 2.

Compound 2 was obtained as a white powder, $[\alpha]_{\mathrm{D}}^{20}+3.0^{\circ}(c$ $0.185, \mathrm{MeOH})$. The molecular formula of 2 was established as $\mathrm{C}_{29} \mathrm{H}_{34} \mathrm{O}_{11}$ at $m / z 581.2003$ (calcd. 581.1993) [M + Na] $]^{+}$, identical with that of $\mathbf{8}$ and $\mathbf{9}$. The NMR spectrum of $\mathbf{2}$ also displayed high similarity with those of $\mathbf{8}$ and $\mathbf{9}$, which implied that $\mathbf{2}$ might be an isomer of $\mathbf{8}$ and $\mathbf{9}$. The HMBC experiment of $\mathbf{2}$ showed two distinct correlations, i.e., the anomeric proton (Glc H-1, $\delta 5.06)$ with C-3 ( $\delta 80.9)$, and Glc H-4 ( $\delta 5.69)$ with C-8' ( $\delta 172.3)$, which supported the connectivity between the glucose moiety with the 3hydroxy group of the sesquiterpene skeleton and also the linkage point of the $p$-hydroxyphenylacetyl group on the G-4 position. Therefore, the structure of $\mathbf{2}$ was identified as 4 '-p-hydroxyphenylacetyl crepiside $\mathrm{E}$.

The other purified components 3-10 were identified as isolipidiol (3) [12], isoamberboin (4) [13], grosheimin (5) [14], annuionone D (6) [15], loliolide (7) [16], youngiajaponicoside A (8) [17], crepiside $H(9)$ [18], and crepiside $E(10)$ [18] by direct comparison of their spectral data with those in the literature.

All isolated compounds (1-10) from Y. japonica were examined for inhibitory effects on proliferative of human cancer cell lines A549 (nonsmall cell lung carcinoma), SK-OV-3 (ovary malignant ascites), SK-MEL-2 (skin melanoma), and HCT15 (colon adenocarcinoma), according to the SRB assay in vitro [19]. Among the tested compounds, only 5 , which holds the partial structure of the exomethylene $\gamma$-lactone moiety, exhibited a potent cytotoxicity against the A549, SK-OV-3, SK-MEL-2, and HCT15 cell lines with $\mathrm{IC}_{50}$ values of $1.74 \mu \mathrm{M}, 0.96 \mu \mathrm{M}, 1.66 \mu \mathrm{M}$, and $1.51 \mu \mathrm{M}$, respectively. However, compounds $\mathbf{2}$ and $\mathbf{8 - 1 0}$, which lacked the exomethylene $\gamma$-lactone moiety, exhibited poor inhibition on the tested tumor cells $\left(\mathrm{IC}_{50}>30 \mathrm{uM}\right)$.

\section{Materials and Methods}

$\nabla$

\section{General experimental procedures}

NMR spectra were obtained by a Bruker AM 300, 500 and Bruker AVANCE II 800 spectrometers using TMS as an internal standard for ${ }^{1} \mathrm{H}$ NMR, ${ }^{13} \mathrm{C}$ NMR, DEPT, COSY, HMQC, and HMBC. HRESIMS was recorded by the Applied Biosystems Mariner time-of-flight mass spectrometer with an electrospray interface. PreparativeHPLC was performed on a Futecs P-4000 system with a Shimpack prep-ODS(H) kit column $(5 \mu \mathrm{m}, 20 \mathrm{~mm} \times 25 \mathrm{~cm})$.

\section{Plant material}

The whole plants of Y. japonica were collected in May 2007 at the herbarium of the Korea Research Institute of Chemical Technology (KRICT) and were authenticated by Dr. Young Sup Kim. A voucher specimen (KR0498) was deposited at the herbarium of KRICT, Korea.

\section{Extraction and isolation}

The whole plants $(9 \mathrm{~kg}$ ) of $Y$. japonica were soaked in methanol $(\mathrm{MeOH})(2 \times 40 \mathrm{~L})$ at room temperature for 7 days. The $\mathrm{MeOH}$ extract was filtered and evaporated to dryness under reduced pressure. The concentrated extract $(1.4 \mathrm{~kg}$ ) was suspended in $20 \mathrm{~L}$ of water and then extracted successively with an equal volume of dichloromethane (MC), ethyl acetate (EtOAc), and $n$-butanol ( $n$ $\mathrm{BuOH}$ ), which afforded $278 \mathrm{~g}$ of the MC fraction, $20 \mathrm{~g}$ of the EtOAC fraction, $120 \mathrm{~g}$ of the $n-\mathrm{BuOH}$ fraction, and $890 \mathrm{~g}$ of aqueous layer. The repeated chromatographic purification of the MC fraction and EtOAc fraction resulted in the isolation of 1-10. The detailed purification procedures of compounds $\mathbf{1 - 1 0}$ are available in the Supporting Information.

4-epi-isolipidiol (1): White amorphous powder; $[\alpha]_{\mathrm{D}}^{20}+11.7$ (c $0.20, \mathrm{CH}_{3} \mathrm{OH} ;{ }^{1} \mathrm{H}$ NMR (pyridine- $d_{5}, 800 \mathrm{MHz}$ ); ${ }^{13} \mathrm{C}$ NMR (pyridine- $d_{5}, 200 \mathrm{MHz}$ ) (๑ Table 1); HRESIMS $m / z 289.1426[\mathrm{M}+\mathrm{Na}]^{+}$ (calcd. for $\mathrm{C}_{15} \mathrm{H}_{22} \mathrm{O}_{4} \mathrm{Na}, 289.1410$ ).

4'-p-hydroxyphenylacetyl crepiside $E(\mathbf{2})$ : white powder; $[\alpha]_{D}^{20}$ +3.0 (c 0.19, $\mathrm{CH}_{3} \mathrm{OH} ;{ }^{1} \mathrm{H}-\mathrm{NMR}$ (pyridine- $d_{5}, 800 \mathrm{MHz}$ ); $\delta: 2.11$ (1 H, m, H-2b), 2.33 (1 H, m, H-2a), 2.38 (1 H, dd, J=13.6, $4.0 \mathrm{~Hz}$, H-9b), 2.70 (1 H, dd, $J=13.6,4.8 \mathrm{~Hz}, \mathrm{H}-9 \mathrm{a}), 2.80$ (1 H, t, $J=9.6 \mathrm{~Hz}$, H-5), 2.92 (1 H, q, J= 8.8 Hz, H-1), 3.11 (1 H, m, H-7), 3.79 (1 H, d, $J=15.5$ Hz, H-7'a), 3.76 ( 1 H, d, J = 15.5 Hz, H-7'b), 3.97 (1 H, m, Glc H-5), 4.02 (1 H, m, H-8), 4.04 (1 H, m, Glc H-6b), 4.08 (1 H, dd, $J=9.6,7.2 \mathrm{~Hz}$, Glc H-2), 4.14 (1 H, br d, $J=11.2 \mathrm{~Hz}$, Glc H-6a), 4.32 (1 H, dd, J=9.6, 8.8 Hz, Glc H-3), 4.57 (1 H, t, J=9.6 Hz, H-6), 4.82 $(1 \mathrm{H}, \mathrm{t}, J=6.4 \mathrm{~Hz}, \mathrm{H}-3), 5.06(1 \mathrm{H}, \mathrm{d}, J=7.2 \mathrm{~Hz}$, Glc H-1), $5.07(1 \mathrm{H}$, br s, H-14b), 5.14 (1 H, br s, H-14a), 5.60 (1 H, br s, H-15b), 5.69 ( $1 \mathrm{H}, \mathrm{dd}, J=9.6,8.8 \mathrm{~Hz}$, Glc H-4), 5.76 (1 H, br s, H-15a), $6.40(1 \mathrm{H}$, m, H-13b), 6.46 (1 H, m, H-13a), 7.12 (2 H, d, J=8.0 Hz, H-3', 5'), $7.36\left(2 \mathrm{H}, \mathrm{d}, J=8.0 \mathrm{~Hz}, \mathrm{H}-2{ }^{\prime}, 6^{\prime}\right) ;{ }^{13} \mathrm{C}-\mathrm{NMR}$ (pyridine- $d_{5}, 200 \mathrm{MHz}$ ) (๑ Table 2); HRESIMS $\mathrm{m} / z$ 581.2003 $[\mathrm{M}+\mathrm{Na}]^{+}$(calcd. for $\mathrm{C}_{29} \mathrm{H}_{34} \mathrm{O}_{11}$, 581.1993).

isolipidiol (3): White amorphous powder; $[\alpha]_{D}^{20}+13.1$ (c 0.16 , $\mathrm{CH}_{3} \mathrm{OH}$ ); ${ }^{1} \mathrm{H}$ NMR (pyridine- $d_{5}, 800 \mathrm{MHz}$ ); ${ }^{13} \mathrm{C}$ NMR (pyridine- $d_{5}$, $200 \mathrm{MHz}$ ) ( Table 1); EI-MS m/z: $266.1[\mathrm{M}]^{+}$. X-ray crystallographic analysis (๑ Fig. 3 )

\section{Tumor cell culture and cytotoxicity assessment}

All cell cultures were maintained using RPMI 1640 cell growth medium (Gibco) supplemented with $5 \%$ fetal bovine serum (FBS) (Gibco) and grown at $37^{\circ} \mathrm{C}$ in a humidified atmosphere containing $5 \% \mathrm{CO}_{2}$. The human cancer cell lines A549 (nonsmall cell lung carcinoma), SK-OV-3 (ovary malignant ascites), SK-MEL-2 (skin melanoma), and HCT15 (colon adenocarcinoma) were provided by the National Cancer Institute (NCI). The cytotoxicity of isolated compounds (1-10) against cultured human tumor cell lines was evaluated by the SRB method [19]. All compounds (1-10) were purified by HPLC (to 95\% purity) prior to cytotoxicity assessment. Doxorubicin (Sigma-Aldrich; purity > 98\%) was used as the positive control.

\section{Supporting information}

A detailed description of the extraction and isolation of compounds 1-10, and spectral graphs of compounds 1-3 are available as Supporting Information. 
Table $2{ }^{13}$ C-NMR spectroscopic data of $\mathbf{2 , 8}, \mathbf{9}$, and $\mathbf{1 0}$

\begin{tabular}{|c|c|c|c|c|}
\hline No. & $2^{\text {a) }}$ & $8^{\text {b) }}$ & 9a) & $10^{\mathrm{a})}$ \\
\hline 1 & 46.5 & 46.6 & 46.5 & 46.4 \\
\hline 2 & 38.7 & 38.7 & 39.0 & 38.9 \\
\hline 3 & 80.9 & 80.8 & 81.4 & 81.0 \\
\hline 4 & 150.3 & 150.2 & 150.6 & 150.7 \\
\hline 5 & 52.5 & 52.5 & 52.5 & 52.4 \\
\hline 6 & 79.3 & 79.1 & 79.5 & 79.5 \\
\hline 7 & 51.4 & 51.2 & 51.5 & 51.5 \\
\hline 8 & 72.5 & 72.6 & 72.2 & 72.2 \\
\hline 9 & 43.0 & 42.5 & 43.4 & 43.2 \\
\hline 10 & 144.1 & 144.8 & 144.9 & 144.9 \\
\hline 11 & 141.1 & 141.0 & 141.0 & 141.1 \\
\hline 12 & 170.6 & 170.0 & 170.7 & 170.7 \\
\hline 13 & 122.1 & 121.5 & 122.1 & 122.2 \\
\hline 14 & 116.7 & 116.6 & 116.8 & 116.8 \\
\hline 15 & 115.1 & 114.7 & 115 & 114.8 \\
\hline \multicolumn{5}{|c|}{ Sugar moiety } \\
\hline G-1 & 103.3 & 102.3 & 104.1 & 104.3 \\
\hline G-2 & 75.8 & 73.2 & 75.6 & 75.8 \\
\hline G-3 & 76.1 & 79.1 & 75.6 & 79.1 \\
\hline G-4 & 73.3 & 69.9 & 72.6 & 72.6 \\
\hline$G-5$ & 76.4 & 77.4 & 78.7 & 79.0 \\
\hline G-6 & 62.5 & 62.6 & 65.6 & 63.3 \\
\hline \multicolumn{5}{|c|}{ p-Hydroxyphenylacetic acid moiety } \\
\hline $1^{\prime}$ & 125.7 & 126.3 & 125.8 & \\
\hline $2^{\prime}, 6^{\prime}$ & 131.5 & 131.3 & 131.5 & \\
\hline $3^{\prime}, 5^{\prime}$ & 116.7 & 115.9 & 116.9 & \\
\hline $4^{\prime}$ & 158.4 & 157.1 & 158.5 & \\
\hline $7^{\prime}$ & 41.2 & 40.7 & 41.1 & \\
\hline $8^{\prime}$ & 172.3 & 172.1 & 172.7 & \\
\hline
\end{tabular}

a) In pyridine- $d_{5}$ solution, ${ }^{b}$ ) in acetone- $d_{6}$ solution

\section{Acknowledgements}

This research was supported by the research fund of NRF2012M3A9C and also by a grant of the Technology Innovation Program (10038744) of the Korea Evaluation Institute of Industrial Technology (KEIT), Republic of Korea.

\section{Conflict of Interest}

The authors have no conflict of interest to declare.

\section{References}

1 Kim IS, Seo BB, Song SD, Park JH, Lee MO, Kim JS. The identification of unrecorded subspecies of Youngia japonica. Kor J plant Tax 2000; 30: 55-73

2 Jang DS, Ha TJ, Choi SU, Nam SH, Park KH, Yang MS. Isolation of isoamberboin and isolipidiol from whole plants of Youngia japonica (L.) DC. Kor J Pharmacogn 2000; 31: 306-309

3 Lee WB, Kwon HC, Yi JH, Choi SU, Lee KR. A new cytotoxic triterpene hydroperoxide from the aerial part of Youngia japonica. Yakhak Hoeji 2002; 46: $1-5$

4 Dat NT, Cai XF, Bae KH, Kim YH. Terpenoid constituents from Youngia koidzumiana. Nat Prod Sci 2002; 8: 55-57
5 Adegawa S, Miyase T, Fukushima S. Sesquiterpene glycosides from Youngia denticulata (Houtt.) Kitam. Chem Pharm Bull 1986; 34: 3769-3773

6 Arai Y, Wama M, Ageta H. Composite constituents: aliphatics and triterpenoids isolated from the aerial parts of Youngia denticulata. Yakugaku Zasshi 1982; 102: 1089-1091

7 Jo YM, Suh JY, Bae SJ, Jung JH, Im KS. Sesquiterpene lactones from the roots of Ixeris sonchifolia. Nat Prod Sci 2005; 11: 55-57

8 Srivastava RP, Proksch P, Wray $V$. Toxicity and antifeedant activity of a sesquiterpene lactone from Encelia against Spodoptera littoralis. Phytochmistry 1990; 29: 3445-3448

9 Ahn EM, Bang MH, Song MC, Park MH, Kim HY, Kwon BM, Baek NI. Cytotoxic and ACAT-inhibitory sesquiterpene lactones from the root of Ixeris dentata forma albiflora. Arch Pharm Res 2006; 29: 937-941

10 Gonzalez AG, Garcia BM, Breton J. Terpenoids of compositae. X. Structure of grosshemin, lipidiol, and isolipidiol. Lactones of Amberboa lipii and their stereochemistry. Anales de Quimica 1970; 66: 799-811

11 Cha MR, Choi YH, Choi CW, Yoo DS, Kim YS, Choi SU, Kim YH, Ryu SY. New guaiane sesquiterpene lactones from Ixeris dentata. Planta Med 2011; 77: $380-382$

12 Fazylova AS, Turdybekov KM, Kadirberlina GM, Rakhimova BB, Adekenov $S M$. Molecular structure of crepidioside a and isolipidiol from Crepis multicaulis. Chem Nat Cmpd 2000; 36: 177-180

13 Jang DS, Ha TJ, Choi SU, Nam SH, Park KH, Yang MS. Isolation of isoamberboin and isolipidiol from whole plants of Youngia japonica (L.) DC. Kor J Pharmacogn 2000; 31: 306-309

14 Oksuz S, Ulubelen A, Aynechi Y, Wagner H. A guaianolide from Centaurea behen. Phytochemistry 1982; 21: 2747-2749

15 Xie XD, Niu YF, Lai PX, Row KH. Sesquiterpenoids and other constituents from Senecio argunensis. Chem Pharm Bull 2010; 58: 991-994

16 He Z, Zhang A, Ding L, Lei X, Sun J, Zhang L. Chemical composition of the green alga Codium divaricatum Holmes. Fitoterapia 2010; 81: 11251128

17 Chen WL, Liu QF, Wang J, Zou J, Meng DH, Zuo JP, Zhu XZ, Zhao WM. New guaiane, megastigmane and eudesmane-type sesquiterpenoids and anti-inflammatory constituents from Youngia Japonica. Planta Med 2006; 72: 143-150

18 Miyase T, Yamada M, Fukushima S. Studies on sesquiterpene glycoside from Prenanthes acerifolia BENTH. Chem Pharm Bull 1987; 35: 19691974

19 Skehan P, Storeng R, Scudiero D, Monks A, McMahon J, Vistica D, Warren $J T$, Bokesch H, Kenney S, Boyd MR. New colorimetric cytotoxicity assay for anticancer-drug screening. J Natl Cancer Inst 1990; 82: 1107-1112

received April 13, 2015

revised June 30,2015

accepted June 30, 2015

Bibliography

Dol http://dx.doi.org/10.1055/s-0035-1557794

Planta Med Lett 2015; 2: e31-e34

(c) Georg Thieme Verlag KG Stuttgart · New York .

ISSN 2199-157X

\section{Correspondence}

Ph. D. Shi Yong Ryu

Korea Research Institute of Chemical Technology

141 Gajeongro, Yuseong

Daejeon 305-600

Korea

Phone: +82428607163

Fax: +82428617160

syryu@krict.re.kr 